\title{
Self Control Counseling for Students during Covid-19 through Al-Islam and Kemuhammadiyahan Curriculum
}

\author{
Ahmad Lahmi ${ }^{1}$, Mahyudin Ritonga ${ }^{1, *}$, Raviusman $^{1} \&$ Yusida Imran ${ }^{2}$ \\ ${ }^{1}$ Muhammadiyah University of West Sumatera, Indonesia \\ ${ }^{2}$ Universitas Muhammadiyah Pontianak, Indonesia \\ *Correspondence: Muhammadiyah University of West Sumatera, Indonesia. E-mail: mahyudinritonga@gmail.com
}

Received: October 26, 2021

Accepted: December 22, 2022 Online Published: January 21, 2022

doi: $10.5430 /$ jct.v11n2p35

URL: https://doi.org/10.5430/jct.v11n2p35

\begin{abstract}
The Covid-19 outbreak has not only changed the economic, social, and educational systems but has also affected the psychology of students. This study aimed to explore the form of self-control counseling for students through Al-Islam and Kemuhammadiyahan during Covid-19. This study is important considering AIK as a compulsory curriculum in Muhammadiyah schools and colleges to form students cognitively and form an emotionally and spiritually mature generation. This study was designed with a qualitative approach with data sources namely AIK teachers and students through purposive sampling. Based on the results, first, AIK material has the power to provide counseling to students in situations faced with life problems. Second, self-control counseling through AIK provides strength and emotional maturity for students to accept God's provisions. Third, the forms of self-control counseling provided to students during the Covid-19 period are in the form of personal counseling, worship counseling, study counseling, and organizational counseling.
\end{abstract}

Keywords: personality, counseling, self control, AIK Curriculum

\section{Introduction}

The emotional state to accept difficult situations as trials from Allah is an important thing to have. This statement is based on the results of various studies and the idea that the calm and emotional comfort of students has a major influence on learning achievement (Datu, 2017), learning outcomes (Harber \& Sakade, 2009), and learning quality (Alghamdi, 2021). Some of these conclusions can also be interpreted that students who are uneasy during learning will cause low learning outcomes.

Along with the statement above, the Covid-19 situation has caused significant changes in various aspects of life. For example in the education aspect where the learning system is transferred online. In addition, the economy is difficult to meet daily needs and even psychological changes due to concerns about the Covid-19 virus. When it has disturbed human psychology, humans will find it difficult to get through that difficult time.

The SMP Muhammadiyah 1 Teluk Kuantan students in the initial observation seemed to have changed because of the Covid-19. Emotional changes are reflected in the way a person communicates with friends, teachers, and others. Due to Covid-19, not a few students avoid socializing completely, do not want to communicate, do not want to hang out with friends. On the one hand, such an attitude is a good thing to avoid the spread of the Covid-19 Virus. But on the other hand, building a relationship with the surrounding community is the most important thing, because avoiding the virus does not have to cut off direct communication but simply keeps a distance.

In addition, there are several cases where students do not want to pick up or deliver assignments to school on the grounds that their bodies are not fit, even though they are in good health. Another reality, there are students who are not serious about completing the given task. This fact shows that the mentality, emotion, and spirituality at SMP Muhammadiyah 1 have changed due to Covid-19. On the other hand, optimism then emerged to strengthen AIK learning at SMP Muhammadiyah 1 Kuantan Singingi to minimize the decline in mental, emotional, and spiritual tendencies.

Optimism to restore self-control through AIK learning is actually based on the purpose of AIK as a mandatory 
curriculum in Muhammadiyah schools and colleges. Arifin stated that the purpose of AIK at Muhammadiyah educational institutions is to form students with strong spirituality, dynamic mindset, competitive spirit, and entrepreneurship (Arifin, 2015). Ritonga et al also stated that AIK as a compulsory curriculum in Muhammadiyah colleges aims to form students to be able to understand Islamic teachings comprehensively (Ritonga et al., 2021). Humans who fully understand religious teachings have emotionally and spiritually healthy personalities (Koenig, 2012; Anwar et al., 2020).

The conclusions of the experts above are based on the existence of religion to direct humans to conform to God's rules. The existence of the holy book as a way of life always contains teachings so that humans are physically and spiritually healthy (Bensaid et al., 2014). Rasyid et al stated that the Al-Quran directs humans to have common sense so that it leads to physical health (Rasyid et al., 2020). The conclusion above shows that the existence of religion is the basis for forming healthy emotions and spirituality. Therefore, the existence of a religious-based curriculum in each educational unit is not only to broaden cognitive horizons but also to mature emotionally.

Another study found that religious education makes a significant contribution to the mental health development of students (Estrada et al., 2019; Harianto et al., 2021; Ritonga et al., 2021). A different conclusion was expressed by Sadida and Triman, from 52 respondents, there was no difference in the social and emotional skills of students studying at KAF and studying at other institutions (Sadida \& Triman, 2019). Kuttab Alfatih is an educational institution that has a special curriculum for the religious field (Saugi, 2020).

The differences in the findings above are the basis for researchers to emphasize the importance of this study. Therefore, the purposes of this study were first, to reveal the harmony between AIK material and self-control counseling for students, secondly, to find the direction of self-control counseling for students in AIK learning, and thirdly, to reveal forms of self-control counseling in AIK learning.

\section{Method}

This study was carried out in SMP Muhammadiyah 1 Kuantan Singingi due to changes in the self-control of students during Covid-19. This study was conducted with a qualitative approach because of the intention to reveal data naturally (Mirhosseini \& Noori, 2019). A study can be said to be natural if the conditions and situations at the time of the study are not influenced by experiments or settings.

The key informants in this study were AIK teachers at SMP Muhammadiyah 1 Teluk Kuantan because of their sufficient knowledge related to AIK content and relevance to self-control counseling. Researchers make students additional informants to measure the accuracy of the data given by key informants.

To obtain data from key informants and additional informants, researchers used observations, interviews, and documentation studies. The observation was conducted on activities taking place in the school environment to find out facts related to the study content. Researchers conducted unstructured interviews to provide freedom to informants. Meanwhile, documentation study was used to interpret data in school documents according to study content such as AIK learning resources, AIK teacher notes, and other related documents.

The data were analyzed interactively based on the concept developed by Miles and Huberman as shown in Figure 1.

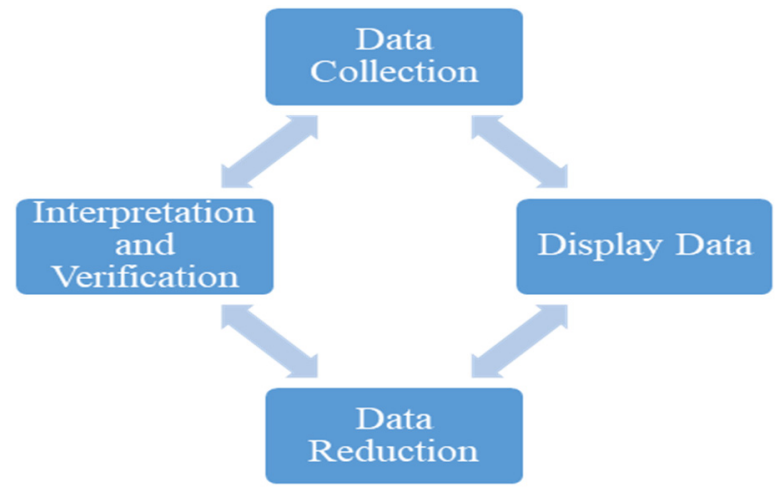

Figure 1. Interactive Data Analysis Technique (Miles \& Huberman, 1994) 
The use of the above analysis techniques is intended to understand and interpret the data and to ensure data validity. Therefore, the data analysis took place simultaneously from data collection to drawing conclusions.

\section{Results and Discussion}

\subsection{Relevance of AIK Materials with Self Control Counseling for Students at SMP Muhammadiyah 1 Kuantan Singingi}

The age of students at the junior high school level is included in the transition period, students try a lot to find their identity with various activities, and not a few students are found doing things that violate legal norms, religious norms, customs, and other norms.

In the AIK curriculum, there are several materials relevant to self-control counseling for students. This view is based on the curriculum structure compiled by experts including the Qur'an, Aqidah, Morals, Jurisprudence, Kemuhammadiyahan, and Arabic (Dikdasmen, 2017). (Stavrova et al., 2020; Adlya et al., 2020).

Individuals who have self-control can be identified by the ability to control themselves from impulsive behavior, the ability to delay gratification, and the ability to anticipate situations with objective considerations (Informan, Interview; 2020).

The relevance between AIK material and self control counseling can be found in Figure 2.

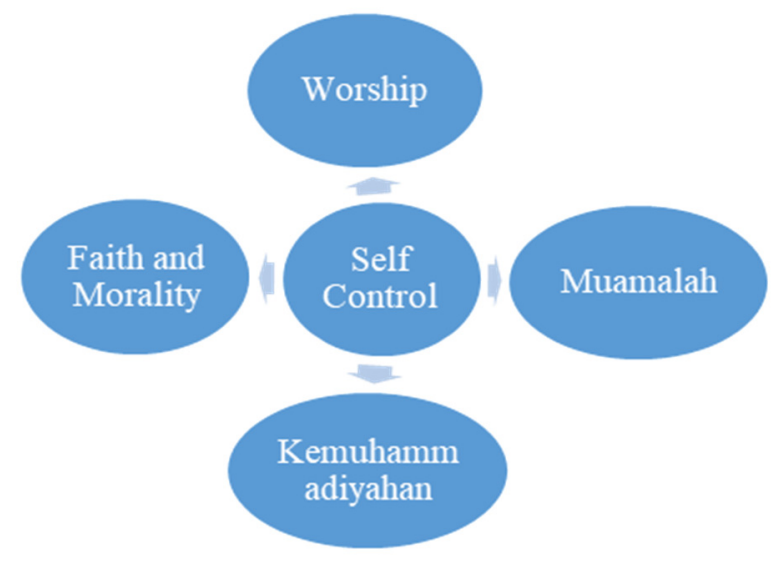

Figure 2. Self Control in AIK Curriculum

The AIK on Faith and Morality curriculum leads to counseling for students to control themselves in any condition. The outcome of this subject is that students have the strength of faith and behave according to the rules of Allah and His Messenger. The Covid-19 condition does not become a barrier for students with strong faith to continue to have passion in exploring knowledge. This is in line with a statement by Clark et al that belief in God has an impact on human emotional health (Clark et al., 2017). Lynn et al also stated that every job carried out on the basis of faith has a different impact from work without the basis of faith (Lynn et al., 2011).

Another aspect of the AIK curriculum is worship. This material forms students to be obedient to worship God. Worship in Islam is not limited to mahdhah (Marzband et al., 2016), but all work that is carried out sincerely will become worship, therefore, learning and all activities related to learning will be worth worship. If every job will be worth worship, the Covid-19 condition will not be a barrier to worship.

Muamalah is an important part of students in AIK learning with the aim that students have the ability to build good interactions with everyone. Kemuhammadiyahan is part of the mandatory content in the AIK curriculum with the aim that students have leadership, partnership, entrepreneurship, and optimism.

Based on the above analysis, the AIK curriculum in Muhammadiyah schools and colleges leads to self-control counseling for students. The breadth of the scope and content of the AIK curriculum not only forms self-control for students in social aspects but also religious aspects. 


\subsection{Direction of Self Control Counseling Through AIK Learning}

Student changes in learning activities at SMP 1 Muhammadiyah were the main focus of self-control counseling for students. Therefore, the content in the AIK curriculum becomes a reference for self-control counseling for students. From the content of the AIK curriculum, accompanied by the results of observations, interviews, and documentation studies, it is known that the direction of self-control counseling at SMP 1 Muhammadiyah Kuantan Singingi is in accordance with Figure 3.

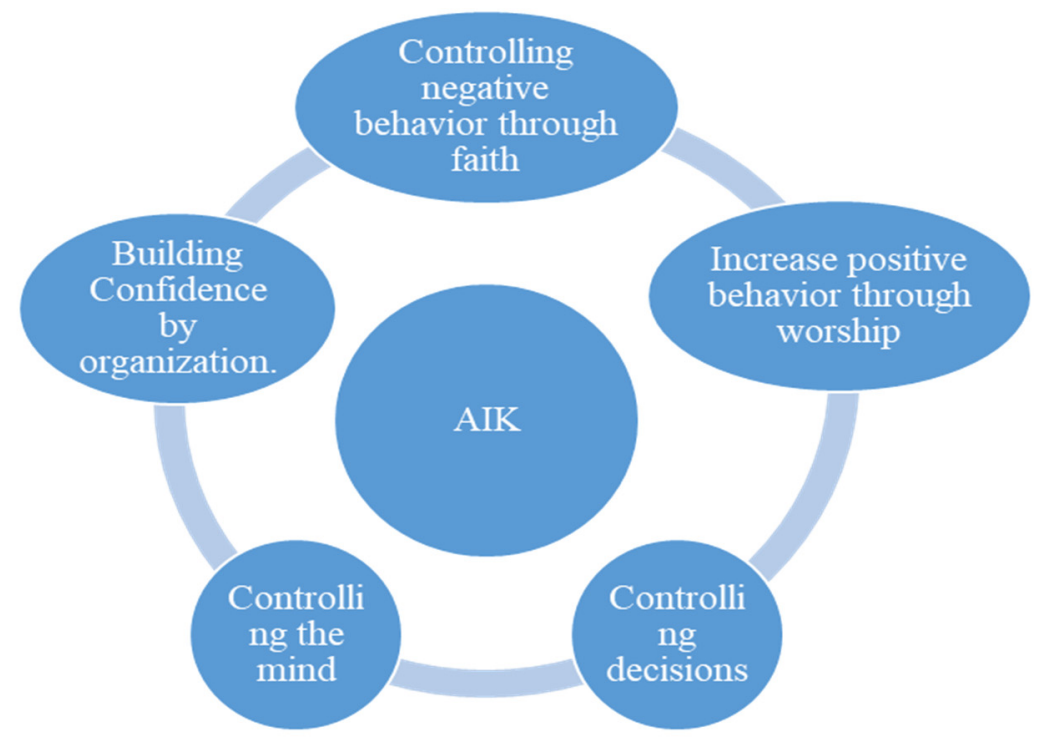

Figure 3. Direction of Self Control Counseling Through AIK Learning

Based on Figure 3, through AIK, self-control can be fostered, because in AIK there is material on how students have the ability to control themselves from negative behavior. The ability to avoid negative behavior along with the material in aspects of Aqidah and Morals as part of the AIK curriculum. This is in line with a study by Hidayah (2021) that the level of good and bad human behavior cannot be separated from their ability to distinguish between good and bad aspects.

Another self-control counseling contained in AIK learning is forming students with self-confidence. Students at SMP 1 Muhammadiyah during the Covid-19 period seemed to have a pessimistic attitude toward gaining knowledge through online learning. However, the existence of Muhammadiyah is seen as having an impact on growing optimism.

Worship as an aspect of AIK also helps build self-control. When students carry out various worships, positive behavior will be fulfilled in themselves. This is in line with a study by Hamidah et al that the existence of religious activities shapes positive behavior for students (Hamidah et al., 2021). Another conclusion confirms that religious practice produces students with positive behavior (Fagan, 2010; Hidayah et al., 2021).

In AIK learning there is also self-control counseling related to decision control and mind control. The Covid-19 condition made students at SMP 1 Muhammadiyah unable to control the decision to continue studying according to the instructions given by the school. This reality is in line with the inability of studies to control the mind so that positive thoughts seem to disappear from students. Therefore, through AIK learning, students are fostered in the aspect of making decisions and thinking. This aspect can be realized because the material in AIK instills optimism in facing every problem in life.

\subsection{Forms of Self Control Counseling through AIK Learning}

SMP 1 Muhammadiyah has adequate facilities to conduct self-control counseling for students. The data proves that the existence of the AIK teacher room, mosque as a place of worship, counseling room for BK teachers and the Muhammadiyah Student Association (IPM) room are the capital for this institution in serving forms of self-control counseling for students.

In accordance with the data found, students at SMP 1 Muhammadiyah received self-control counseling in the form of: 


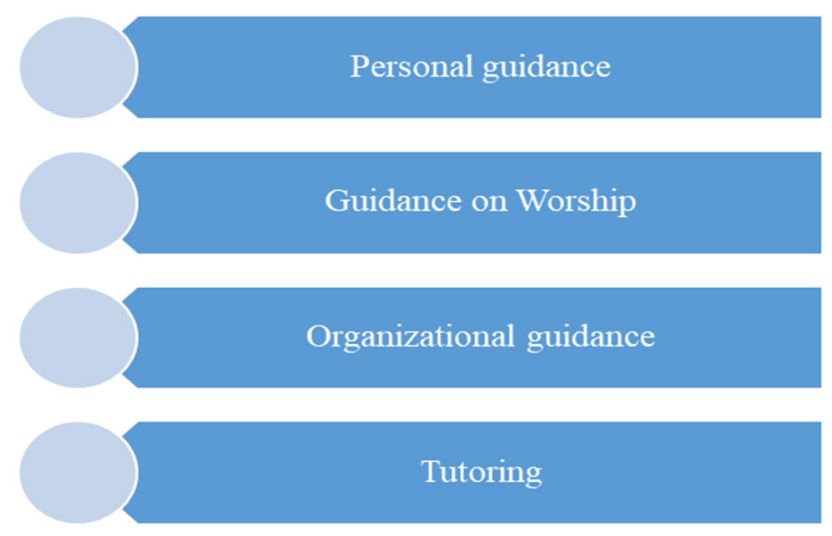

Figure 4. Forms of Self Control Counseling during aCovid-19 at SMP 1 Muhmmadiyah

Personal counseling at SMP 1 Muhammadiyah Kuansing Singingi is given to students to understand their inner state so that they can solve problems and struggles within themselves. The Covid-19 condition requires counseling in this form, so as to minimize confusion in thinking. The function of personal counseling carried out at SMP 1 Muhammadiyah Kuantan Singingi is the same as a statement by Ng'eno and Magut that personal counseling to students can clarify the direction of their self-development (Ng'eno \& Magut, 2014).

The Covid-19 situation also requires SMP 1 Muhammadiyah to conduct worship counseling. According to the informant, this counseling aims to provide comfort and tranquility for students. This finding is in line with the conclusion of Hidayah et al that worship provides peace for the believers (Hidayah et al., 2021). Another form of counseling at SMP 1 Muhammadiyah Kuantan Singingi in fostering self-control students is the learning counseling. In practice, this counseling is given to students who do not show any development of knowledge during the online learning process, therefore, the school provides special services for students in such a way when they are present in the school environment.

As an educational institution under the auspices of Muhammadiyah, SMP 1 Muhammadiyah also provides self-control counseling through organizational counseling. This form of counseling is given to strengthen students' optimism in dealing with various life problems, including the impact caused by Covid- 19 .

\section{Conclusion}

The Covid-19 condition has had many impacts on humans around the world, the impact is not only on the physical aspect but also the human psyche has changed due to the Covid-19 pandemic. Psychological changes that occur in students can be minimized by setting policies to conduct self-control counseling. SMP 1 Muhammadiyah Kuantan Singingi has implemented self control counseling, the counseling activities carried out are proven to provide emotional maturity for students. The success of self-control counseling carried out at SMP 1 Muhammadiyah is supported by the AIK curriculum which contains several materials related to self-control.

\section{Acknowledgements}

The author thanked the various parties who have provided support for the continuity and completion of our research. Thank you to the Rector of the Muhammadiyah University of West Sumatra, who has fully supported all research activities. The regional leader of Muhammadiyah Kuantan Singingi Regency, all lecturers of graduate programs at Postgraduate Muhammadiyah University of West Sumatra, especially those from Kuantan Singingi Regency.

\section{References}

Adlya, S. I., Yusuf, A. M., \& Effendi, M. (2020). The contribution of self control to students' discipline. Journal of Counseling and Educational Technology, 3(1), 1-5. https://doi.org/10.32698/0791

Alghamdi, A. A. (2021). Impact of the COVID-19 pandemic on the social and educational aspects of Saudi university students' lives. PLoS ONE, 16(4 April), 1-18. https://doi.org/10.1371/journal.pone.0250026

Anwar, M. A., Gani, Aa. M. O., \& Rahman, M. S. (2020). Effects of spiritual intelligence from Islamic perspective on emotional intelligence. Journal of Islamic Accounting and Business Research, 11(1), 216-232. 
https://doi.org/10.1108/JIABR-10-2016-0123

Arifin, S. (2015). Rekonstruksi Al-Islam Kemuhammadiyahan (AIK) Perguruan Tinggi Muhammadiyah Sebagai Praksis Pendidikan Nilai. EDUKASI: Jurnal Pendidikan Agama Dan Keagamaan, 13(2), 201-221.

Bensaid, B., Machouche, S. B. T., \& Grine, F. (2014). A Qur'anic framework for spiritual intelligence. Religions, 5(1), 179-198. https://doi.org/10.3390/rel5010179

Clark, E. M., Huang, J., Roth, D. L., Schulz, E., Williams, B. R., \& Holt, C. L. (2017). The relationship between religious beliefs and behaviors and changes in spiritual health locus of control over time in a national sample of African Americans. Ment Health Relig Cult, 20(5), 449-463. https://doi.org/10.1080/13674676.2017.1356274.The

Datu, J. A. D. (2017). Peace of Mind, Academic Motivation, and Academic Achievement in Filipino High School Students. The Spanish Journal of Psychology, 20(e22), 1-8. https://doi.org/10.1017/sjp.2017.19

Dikdasmen, M. (2017). Kurikulum Pendidikan Al-Islam, Kemuhammadiyahan dan Bahasa Arab. In Baedhowi, T. Hamami, Masykuri, Suwadi, A. B. Raharjo, A. Muhammad, F. Setiawan, N. H. Kurniawan, B. Mustakim, Sarjono, Casmini, H. Widodo, Ridwan, Suyatno, M. Ali, \& M. Yusuf (Eds.), Jakarta: Pimpinan Pusat Muhammadiyah. Majelis Dikdasmen.

Estrada, C. A. M., Lomboy, M. F. T. C., Gregorio, E. R., Amalia, E., Leynes, C. R., Quizon, R. R., \& Kobayashi, J. (2019). Religious education can contribute to adolescent mental health in school settings. International Journal of Mental Health Systems, 13(1), 1-6. https://doi.org/10.1186/s13033-019-0286-7

Fagan, P. F. (2010). Religious Practice and Educational Attainment. Marriage \& Religion Research Institute, September, 1-22. Retrieved from http://marri.us/wp-content/uploads/Religious-Practice-and-Educational-Attainment.pdf.

Hamidah, I., Mansyur, A. S., Supiana, \& Erihadiana. (2021). Development of Student Islamic Behavior Through Worship Practice Activities at SMAN City of Bandung. Journal of Social Science, 2(4), 381-393. https://doi.org/https://doi.org/10.46799/jss.v2i4.183

Harber, C., \& Sakade, N. (2009). Schooling for violence and peace: how does peace education differ from 'normal' schooling? Journal of Peace Education, 6(2), 171-187. https://doi.org/10.1080/17400200903086599

Harianto, Ritonga, M., \& Saputra, R. (2021). How is the Ability of Islamic Religious Education Teachers in Designing and Using ICT Media? Proceedings of the 1st International Conference on Education, Humanities, Health and Agriculture, ICEHHA 2021. https://doi.org/10.4108/eai.3-6-2021.2310749

Hidayah, R. (2021). Students' Self-Adjustment, Self-Control, and Morality. Journal of Social Studies Education Research, 12(1), 174-193.

Hidayah, R., Mu'awanah, E., Zamhari, A., Munardji, \& Naqiyah. (2021). Learning worship as a way to improve students' discipline, motivation, and achievement at school. Journal of Ethnic and Cultural Studies, 8(3), 292-310. https://doi.org/10.29333/ejecs/748

Koenig, H. G. (2012). Religion, Spirituality, and Health: The Research and Clinical Implications. International Scholarly Research Network ISRN Psychiatry, 2012, 1-33. https://doi.org/10.5402/2012/278730

Lynn, M. L., Naughton, M. J., \& VanderVeen, S. (2011). Connecting religion and work: Patterns and influences of work-faith integration. Human Relations, 64(5), 675-701. https://doi.org/10.1177/0018726710386396

Marzband, R., Hosseini, S. H., \& Hamzehgardeshi, Z. (2016). A concept analysis of spiritual care based on Islamic sources. Religions, 7(6), 1-11. https://doi.org/10.3390/rel7060061

Miles, M. B., \& Huberman, A. M. (1994). Qualitative Data Analysis (2nd ed.). Sage Publication.

Mirhosseini, S. A., \& Noori, M. (2019). Doing qualitative research: the craft of naturalistic inquiry. Educational Action Research, 27(2), 331-333. https://doi.org/10.1080/09650792.2018.1527238

Ng'eno, G. K., \& Magut, A. (2014). Students ' perception of the impact of Guidance and Counseling programmes on the Satisfaction of Vocational needs in selected Kenyan secondary schools . Journal of Education and Practice, 5(36), 171-179.

Rasyid, A., Ritonga, M., Lahmi, A., Nurdianto, T., Ritonga, R., \& Ritonga, S. (2020). What AL-Quran Say About 'Aql. European Journal of Molecular and Clinical Medicine, 7(11), 228-234. 
Ritonga, M., Widodo, H., Munirah \& Nurdianto, T. (2021). Arabic language learning reconstruction as a response to strengthen Al-Islam studies at higher education. International Journal of Evaluation and Research in Education, 10(1), 355-363. https://doi.org/10.11591/ijere.v10i1.20747

Ritonga, M., Lahmi, A., Sartika, F., Zubaidah \& Annova, F. (2021). The Using YouTube and Google Drive as Arabic Learning Media at Covid-19 Period. Proceedings of the 1st International Conference on Education, Humanities, Health and Agriculture, ICEHHA 2021. https://doi.org/10.4108/eai.3-6-2021.2310751

Sadida, N., \& Triman, A. (2019). The Benefit of Islamic Faith Education to Enhance Children Social and Emotional Skills. Jurnal Pendidikan Islam, 4(2), 103-115. https://doi.org/10.15575/jpi.v4i2.1863

Saugi, W. (2020). Implementation of Curriculum Kuttab Al-Fatih on Children at an Early Age. Jurnal Obsesi : Jurnal Pendidikan Anak Usia Dini, 5(1), 70. https://doi.org/10.31004/obsesi.v5i1.510

Stavrova, O., Pronk, T., \& Kokkoris, M. D. (2020). Finding meaning in self-control: The effect of self-control on the perception of meaning in life. Self and Identity, 19(2), 201-218. https://doi.org/10.1080/15298868.2018.1558107

\section{Copyrights}

Copyright for this article is retained by the author(s), with first publication rights granted to the journal.

This is an open-access article distributed under the terms and conditions of the Creative Commons Attribution license (http://creativecommons.org/licenses/by/4.0/). 